\title{
Cosmopolitan Capital and the Internationalisation of the Field Business Elites: Evidence from the Swiss Case ${ }^{1}$
}

(7247 Words)

\begin{abstract}
The aim of this contribution is to explore how the recent internationalisation and the increasing importance of "cosmopolitan capital" has impacted the structure and character of the field of the Swiss business elite. For this purpose we will develop the notion of cosmopolitan capital and comparatively investigate the field of the Swiss Business elite in 1980, 2000 and 2010 with multiple correspondence analysis. We can show that in this period international managers with transnational careers and networks not only grow in number, but come to conquer the apex of the biggest and highest capitalised Swiss firms. At the same time national forms of capital lose in importance and Swiss managers themselves differentiate increasingly into a national and an international fraction.
\end{abstract}

\section{The Internationalisation of Business Elites: the Swiss Case}

'Eight?' was the answer Brady Dougan, CEO of the traditional Swiss bank Credit Suisse, gave to the Swiss weekly Das Magazin when they asked him for the number of federal councillors (the members of the Swiss government) in an interview published in April 2011. Not only did he not know ('seven' would have been the right answer), but he also was obviously not afraid of being publically ignorant about Swiss political life. In 2010 as the CEO of global player Credit Suisse, Dougan apparently felt it was no longer important to have an ear to the ground for Swiss politics. Thirty years earlier, Rainer E. Gut, the person 
who sat in the same office at the top of the Credit Suisse building at Zurich's Paradeplatz, did not only know all, but also shared a longstanding political, business and personal exchange with several of the federal councillors. What is more, he ranked as a captain of the Swiss Army, sat on the committee of the powerful Swiss banking association and presided over (as the president of the board of Nestlé) the most important informal meeting of the Swiss business elite, the Rive Reine conference. Arguably, he was one of the nationally best networked businessmen in Switzerland (Lüchinger and Nolmans, 2003).

Structurally the story of these two men is the story of the reconfiguration of a national field by globalisation. As in many Western countries, in Switzerland for a good part of the $20^{\text {th }}$ century, national business elites functioned and could be understood within a national framework. The national cohesion of business elites through a common national curriculum, national networks and connections to the national political field was dense and systematic — as shown by the example of Rainer E. Gut (Mach et al., 2011). As opposed to this, Brady Dougan, the son of a railroad radio dispatcher from Illinois, has not studied at a Swiss university, does not sit on the board of other large Swiss firms, and has no links to the Swiss army—nor do his knowledge of and links to Swiss politics seem to be particularly profound. On the other hand, Dougan holds an MBA from the University of Chicago's Booth School of Business, is very much at ease in an international context and, as a result of long employment experiences abroad, cultivates a wide network that spreads from the US via Asia to Europe. Therefore, his story is also the story of the declining importance of national knowledge, resources, networks and degrees — and the corollary story of the rising importance of cosmopolitan capital: experiences abroad, international networks, language skills and transnational degrees.

The aim of this contribution is to explore how the recent internationalisation has favoured the emergence of a new kind of resource — cosmopolitan capital—and how this capital has transformed the structure and character of the 'Swiss' business elite ${ }^{2}$. We argue that the recent emergence of international business elites has not replaced the national elites, nor have the transnational elites completely emancipated 
themselves from their national roots. But the growing importance of experience abroad, of English language skills and of international degrees has potentially swirled up the relations of power and the hierarchies in national elite spaces. It is with the concept of 'field' that we will try to analyse the intertwining of the national and the international space. We will examine in particular how international forms of capital are transferred to the Swiss national field and how they interact with the traditional capitals of national or provincial elites (Dezalay, 2004).

Four questions are of particular interest in this context: a) How do the major trends of internationalisation affect the Swiss business elites between 1980 and 2010? b) Do those who possess cosmopolitan capital occupy also economically powerful positions in the Swiss corporate landscape? c) Do those who possess much cosmopolitan capital automatically lack national capitals, or is it possible to be endowed with both forms of capital at the same time? d) Can we also observe a differentiation among Swiss managers according to their internationality?

The paper is organised as follows: In the first part we discuss the interplay between national and international fields and the notion of cosmopolitan capital. Following the presentation of the data and the analytical strategy, we discuss results of the internationalisation of the Swiss business elite and the reconfiguration of the field of the Swiss business elite. In the conclusion we try to relate these results to a wider context.

\section{The Interplay between the National and the International Field}

For about two decades, scholars in the study of business elites have debated the question of whether we can observe the emergence of a transnational business elite. The first studies of the international character of the business elite were network analyses published in the early 1980s (Fennema, 1982; Stokman, 
1986). These were soon followed by complementary qualitative approaches to the ideology and mind-set of this new group (Sklair, 2001). In recent years a controversy came to dominate about whether a truly international business elite exists (Caroll and Fennema, 2002; Kentor and Jang, 2004; Van Veen and Kratzer, 2011). In particular, Kentor and Jang argue that there is a specific transnational group that interacts and share a certain number of social characteristics (educational curricula, meeting places). Not all scholars, however, share this view. Hartmann, for instance, thinks that the recruiting patterns of elites in most European countries remain strongly national and that patterns of circulation between different elite fields still follow national patterns (2011). Caroll, taking an intermediate position, adds for consideration that terms such as 'globalisation' or 'transnationalisation' insinuate to a certain extent that the business elite would have transcended the national framework. Most of empirical analysis, however, shows that this is not the case-transnationalisation does not mean total deconstruction of national boundaries. Managers move to countries with which their home countries entertain particularly close historical, cultural or political relationships — for example, through a common language or former colonial ties (Caroll, 2010; Fligstein, 2006).

It thus seems as though national anchors of the business elite are still in place (recruitment channels, networks, meeting places) and that at the same time an international elite is on the way to being formed. This emerging international elite is probably still shaped by national institutions, structures and resources (Davoine and Ravasi, forthcoming), but at the same time, the new international elite develops its own meeting places, networks and recruiting channels, which are very likely to feed back into and thereby transform the field of national elites.

How can this interaction between the national and the international best be studied? Network analysis has been a promising path so far. Because of its high degree of formal abstraction, it easily allows the connection between national and international actors (or firms) and has therefore already successfully been used in recent studies on the junction of the international and the national (Caroll, 2010; Van Veen 
and Kratzer, 2011). At the same time, network analysis has been criticised for its reliance on narrowly defined and 'epiphenomenal' interactional relations (Bourdieu, 1989) and its failure to integrate potentially more powerful, significant and diverse 'structural' forms of elite coordination, such as a common educational curricula or connections to the political field (Bühlmann et al., forthcoming). As a complementary approach that is able to integrate those structural relations at the intersection of the national and the international, field analysis of Bourdieusian inspiration is what we propose in this contribution.

This might surprise at first, as Bourdieu for a long time used the concept of field only in a national context (Bourdieu, 1989, 1993; see also Savage and Silva in the introduction to this special issue). However, the concept of field can easily be adapted to a new situation where fields are no longer exclusively national. Bourdieu himself opened this line of enquiry with his paper on the circulation of ideas (Bourdieu, 2002) and his reflections on the transition from the national to the international field (Bourdieu, 2000). In the meantime, a series of Bourdieusian researchers have worked on international issues, using more or less explicitly the notion of field (Heilbron, 2001; Gingras, 2002; Dezalay, 2004; Wagner, 2007; Sapiro, 2010). Dezalay's analysis of international professionals, for our case certainly the most useful contribution, states that members of an international elite still base their legitimisation and position on resources acquired in a national framework, while they might use also their international assets to defend certain positions against 'provincial' contesters in a national elite space'.

In other words, he postulates the simultaneous existence of an international and a national field and proposes to study their interaction. When we look at the major characteristics of fields (Bourdieu, 1992; Savage and Silva in the introduction), a certain number of amendments must be made with respect to such an idea of an international field: a field is a more or less autonomous space with a boundary which determines who is part of the field and which is also itself object of the struggles within the field (Bourdieu, 1984; 1989). In the course of the internationalisation of the world economy in the last 30 
years, notably through the liberalisation of exchanges of goods, persons, money or ideas, an international elite field emerged and developed its own relational structures ${ }^{4}$. This system of international positions, however, has maintained and reconfigured structural relations with national elite fields and thereby has contributed to their transformation. As with any field, this international elite field assembles a group of actors who share a common interest in the existence of this field and compete for the same objects of dispute (Bourdieu and Wacquant, 1992). At the same time, these actors are still part of specific national elite fields that are characterised by a series of structural relations between positions that are differently endowed with capital. In these national fields, their international experiences and contacts, so we argue, function as a specific form of capital—which we will call 'cosmopolitan capital'. Whereas 30 years ago this cosmopolitan capital was sometimes an obstacle for elite access to national spaces, it has recently become the fuel of 'subversive' strategies, deployed by new fractions of actors who aim to transform and overthrow the orthodoxy of national elite fields and to disempower the so-far dominant fractions by delegitimising the forms of capital they are relying on ${ }^{5}$.

\section{Cosmopolitan Capital}

For Bourdieu, capital is inherited or acquired resources, whose relative volume or composition gives actors a certain advantage over others within a specific field (Bourdieu, 1986). In analysis of the field of elites, particular attention has been given so far to cultural, economic, social and-sometimes—political capital (Bourdieu and de St. Martin, 1978; Denord et al., 2010; Bühlmann et al., 2012). If social capital relates to the force drawn from 'durable networks of more or less institutionalised relationships of acquaintance and recognition' (Bourdieu, 1986: 51), cultural capital has been mainly used in Bourdieusian elite study in its institutionalised form as an educational qualification. One of the strategies to understand the relationship between the national and the international is the introduction of the notion(s) of international, transnational or cosmopolitan capital (Wagner, 2007). We will first outline how 
this capital could be theorised, then relate it to other forms of capital and finally propose an operationalisation.

To wear the insignia of internationality is without a doubt seen as an asset in certain social groups and professions (Fligstein, 2006; Calhoun, 2003). Even though the nobility and the business bourgeoisie have historically shared an international outlook, for the contemporary managerial business elites it seems to be particularly important to possess cosmopolitan capital (Wagner, 2007). Wagner conceives of international capital as a specific form of cultural capital: according to her, it corresponds above all to a capacity to 'feel at home', even in places which are geographically far away. This can include several aspects: for example, to speak foreign languages, to be familiar with foreign countries and their cultures, to be used to travel or to be at ease in exchanges with people from foreign countries (Wagner, 2007: 43). Others define international capital rather as international social capital (Caroll, 2010). In this view, people belong to informal or formal international networks; for example, they can be observed in international policy groups or transnational interest associations. These international connections would allow the elite members to develop international strategies and to impose their authority on boards of multinational companies and transnational governing bodies such as the European Union or the International Monetary Fund.

The question then rises whether cosmopolitan capital should be considered a specific sub-form of both cultural and social capital or if it should be defined as a new form of capital in its own right. In general, scholars seem to be hesitant with the 'invention' of novel forms of capital (Bennett et al., 2009). And indeed, cosmopolitan cultural capital seems — besides its international character — not to be qualitatively different from embodied or institutionalised states of cultural capital such as those described by Bourdieu (1986). International network contacts, when it comes to social capital, endow their holders with substantially very comparable forms of forces as do national networks. On the other hand, recent studies show that not only among elites, but also within the cultural field in general, the distinction between 
international versus national orientations gains rapidly in importance. This divide is transversal in character as it seems to concern TV preferences, musical tastes, food or political attitudes (Prieur and Savage, 2011: 575). In addition, this opposition seems to mobilise strong moral forces and feelings and is therefore symbolically particularly effective and divisive between fractions of a field (Prieur and Savage, 2011). Finally, those who acquire cultural cosmopolitan capital almost automatically also acquire social cosmopolitan capital — in other words, it is quite likely that the two forms reinforce each other mutually. For these three reasons, we decided — without claiming it is the only valid choice — to add cosmopolitan capital as a supplementary form of capital instead of subsuming it under the categories of cultural and social capital.

When it comes to conceptualisation of this new form of capital, a first strategy could be to treat career experiences as important occasions for the acquisition of cosmopolitan capital. During career stages and sojourns abroad, managers get used to frequent travel between their host and home countries; they are offered the occasions to learn the language and get an impression of the foreign culture. Longer stays in subsidiaries of transnational firms or branches of a foreign firm in their home country may have a rather similar effect. Here people are also regularly confronted with another language, work intensely with colleagues from other countries and may have to travel frequently to the headquarters or branches in other countries. An important aspect of the conceptualisation of these international degrees, experiences or networks is the hierarchy of the countries (Wagner, 2007; Heilbron, 2001). Not all experiences or networks in foreign countries have the same value, particularly in the business world - a clear hierarchy distinguishes very 'international countries' (US, UK) from more 'national countries' ${ }^{6}$. Second, to hold a title from one of the nationally (and at the same time internationally) important universities in the US or the UK (Ivy-league universities or Oxbridge) endows the holder with cosmopolitan capital, even when the person has not internationally travelled to gain this title. A master's degree in business administration (MBA), which often complements national university degrees, can be another indication of the internationality of the person — by contrast to traditional law degrees, which remain much more nationally 
bounded. In the new context of economic globalization, the increasing importance of cosmopolitan capital should thus be related to the declining of typically nationally bounded resources - such as national networks, law degrees or military grades (Bourdieu, 2000).

\section{Data and analytical strategy}

The data were collected as part of the project "Les elites Suisses au XXe siècle: un processus de différenciation inachevé?",7 We include data about the CEOs and presidents of the board of the 110 largest Swiss companies in the years $1980(n=191), 2000(n=184)$ and $2010(n=200)$. The different capitals have been operationalised in the following way:

a) Political capital: this indicator measures the political influence of managers through direct or indirect participation in the political field. We examine membership in economic interest organisations such as Economiesuisse or the Swiss Bankers Association (Econ Interest Assoc Yes/No), the membership in so called extra-parliamentary commissions ${ }^{8}$ (Comm Ex Parl Yes/No) and-in 2010-the general membership in either of these groups (Political Group Yes/No).

b) Social capital: meeting places and networks provide managers with information and can serve as places of negotiation, coordination and identity building. We include three of those meeting places: membership in the most important service club (Rotary Yes/No), rank in the Swiss Army (No Army, Lieutenant, Captain/Major and Colonel) and the degree of centrality within the Swiss company network. The managers are classified according to the numbers of interlocking directorates their firm shares with other large Swiss firms: centrality 1-20, centrality 20-50 and centrality 50+. 
c) Educational capital: here we distinguish the educational level (No University, BA/MA and PhD), the discipline of study (Engineering, Law, Business, Other Education), the university (Berne (Unibe), Basel (Unibas), Zurich (UniZh), St. Gall (Unisg) and the Swiss Federal Institute of Technology (ETHZ)). We also took into account MBA titles - in most of the cases, this is a complementary title and also an indication of an international/transnational orientation.

d) The economic capital encloses the business sector (Machine Industry, Finance Sector, Service Sector and Other Sectors). Sectors such as the finance sector or machine industry are among the most powerful and international and can be considered as indicators of economic power. In addition, we have measured the market capitalisation of companies (Stock not listed, Stock low, Stock middle, Stock high ${ }^{9}$ ) and the number of employees (Employees few, Employees middle and Employees many).

e) When it comes to cosmopolitan capital we firstly distinguish between Swiss managers who pursued their career in Switzerland (Swiss Career Swiss), Swiss managers who pursued their career abroad (Swiss Career International), foreign managers who pursued their career in Switzerland (Foreign Career Swiss), foreigners who pursued a career in their home country (Foreign Career National) and foreigners who pursued an international career (Foreign Career International). According to this gradual classification, the "Swiss Career Swiss-Managers" are the most national category, whereas the "Foreign Career International-Managers" are the most cosmopolitan. Secondly, we examine the type of country people have been to: we distinguish between "Only Switzerland", "European Countries", "Asia, Middle East and Latin America" and "USA, UK and Canada". Thirdly, we have investigated the proportion of employees abroad in the firm they are working in (++ Employees abroad to -- Employees abroad $)^{10}$.

Next, we will describe the internationalisation of the Swiss business elite from 1980 on: the relative growth of international managers, their origins and their career. In a second step we will analyse the role 
of internationality and of cosmopolitan capital within the Swiss field of elites by concentrating on the years 2000 to 2010 (a period of accelerated elite transnationalisation (Caroll, 2010)).

\section{The Inter- and Transnationalisation of the Swiss Business Elite 1980-2010}

During a large part of the $20^{\text {th }}$ century, the Swiss economy was characterised by the opposition between a very international and competitive sector (banks, pharmaceutical industry, machine industry) and a heavily protected and highly cartelised domestic sector (agriculture, construction, beverages). Most of the large Swiss firms, therefore, were already very international and export-oriented from the beginning of the $20^{\text {th }}$ century on.

In the last 30 years, this international orientation has been corroborated in the course of the creation of a common European market and the 'recent globalisation'. In some cases, initially Swiss companies became international by expanding abroad—for instance, by opening more branches in more countries or by buying foreign firms in order to put roots in foreign countries (UBS, Credit Suisse) ${ }^{11}$. In other cases, more frequent in industry, Swiss firms themselves merged with foreign firms (ABB, Adecco, Cementia, Hero). In certain rare cases, transnational firms also moved their headquarters to Switzerland for fiscal reasons (Glencore, Pargesa). Simultaneously—and partially as a consequence of this development—when we examine the corporate leaders (CEOs and presidents of the boards) of the 110 most important 'Swiss' companies, we find that over the last 30 years more and more foreign managers occupy these positionsin 2010 over a third of the top managers were from abroad.

\section{Table 1 about here}


Both as a consequence of - mostly European - mergers and acquisitions and the increasing recruitment of international but 'culturally close' foreign managers ${ }^{12}$, we can speak of an Europeanization of the Swiss business elite between 1980 and 2000. From 2000 on, the proportion of non-European managers—and in particular of Americans_-increases slightly. It seems as if this globalising trend is not the consequence of further mergers and acquisitions (as was common in the 1990s (Van Veen and Kratzer, 2011)) but rather reflects changing recruitment strategies of the big Swiss firms related to the growing importance of the American financial market. Another indicator that could bring light to this question is the type of career these foreign managers have pursued:

\section{Table 2 about here}

In 1980 the few foreign top managers were pursuing their whole careers within Swiss companies, at the apex of which they finally arrived. French citizen Pierre Liotard-Vogt, for example, president of Nestlé's board of directors in 1980, entered the firm in 1933 and from then on worked without interruption in different national branches of the firm. In 2000 this type of integration had lost prevalence, as more and more managers came to Switzerland as a result of mergers or truly international careers. In 2010 this trend continued. The 'adopted' mountaineers are now a minority among foreign managers at the top of Swiss firms, and the truly transnational managers are now by far the most important group. This could be the sign of an increasing legitimacy of cosmopolitan capital and seems to be confirmed, for instance, by the rise of the importance of international MBA degrees among foreign and Swiss top managers alike. To attend such an American form of business school can be interpreted as a sign of the will to complement national educations with a degree that has gained international reputation.

\section{Table 3 about here}


Already in the 1980s and still in 2010, the business schools Swiss managers attended were either the bestrated schools in the US (Harvard, Wharton or Stanford) or European 'imitations' of these models, often based on private initiatives (the Nestlé-founded IMD in Lausanne or the INSEAD in Paris, for example).

In a nutshell, the 'Swiss' business elite has become not only dramatically more international in the last 30 years, but also more extra-European, American and transnational between 2000 and 2010. To understand this development we must relate it to the evolution of national types of capitals among top managers of Swiss firms. Traditionally, Swiss business leaders seek direct and personal political influence through active membership in business associations, political groups or in extra-parliamentary commissions. Also, the Swiss Army plays an important role, both as a common leadership education and as an elite meeting place (Jann, 2003). Table 4 indicates that all of these specifically national resources were in decline between 1980 and 2010.

\section{Table 4 about here}

This is true not only for foreign managers, who for formal reasons are denied access to some of these capitals, but also for their colleagues holding Swiss citizenship. No longer does it seem to be indispensable to have direct connections to parliament, to be present in the political arenas of expertise or to share experiences in the Swiss Army.

Generally, the criteria to gain access to the Swiss business elite seem to have changed dramatically between 1980 and 2010. Whereas Swiss national capitals lose their relevance and legitimacy, experience abroad becomes an asset when it comes to climbing to the apex of large Swiss firms. In order to understand the effects of cosmopolitan capital and its relation to national capitals, we need to analyse the typical constellations within the field of the Swiss economic elite. 


\section{The Field of the Swiss Business Elite in 2000}

In the multiple correspondence analysis, we use all types of capitals as active variables. We first give an indication of the eigenvalues and modified rates of the four most important axes and then present the cloud of categories ${ }^{13}$.

\section{Table 5 about here}

\section{Figure 1 about here}

Five questions mainly contribute to the variance of the first axis (72.0\%): the Internationality of Careers (19.9\%), Military (16.2\%), Type of Country (15.6\%), Employees Abroad (12.1\%) and Network Centrality (8.2\%). The 14 following items whose contribution is above average $(100 / 48=2.10)$ have been retained for the interpretation of the first axis (written in bold in the figure). On the left side of the plane can be found Foreigner Career Swiss (10.8\%), Country Europe (9.2\%), ++ Employees abroad (7.1\%), No Army (6.1\%), No University (4.4\%) and Foreigner Career International (4.1\%). On the right side are located Colonel (6.9\%), Centrality (5.4\%), Country Swiss (5.1\%), Swiss Career Swiss (4.9\%), Rotary Swiss (4.4\%), ETHZ (3.0\%), + Employees abroad (2.2\%) and Law (2.2\%). The variance of the second axis can be explained largely by the following four questions which sum up to 65\%: the Economic Sector (19.6\%), the University (18.8\%), the Educational Level (15.0) and the Number of Employees (11.3\%). For this axis we have retained the 12 following items, indicated in italics in the figure. Situated on the upper half of the figure are Finance Sector (7.4\%), $\mathrm{PhD}$ (7.3\%), Unisg/Unibas (5.5\%), Yes Economic Interest Association (6.0\%), Employees Many (4.9\%), Stock High (4.5\%), Unibe (2.4\%) and Law (2.3\%). In the lower half can be found Machine Industry (11.5\%), ETHZ (9.0\%), BA/MA (7.6\%) and Employees Middle (6.4\%). 
Without a doubt, internationality is an important cleavage of the field of the Swiss business elites in 2000.

The first axis distinguishes between an international fraction on the left and Swiss fraction on the right side of the plane. It seems, however, that this opposition is not linked to economic power: top managers endowed with a high amount of cosmopolitan capital do not more frequently lead firms with a high stock listing or a high number of employees. But neither are they marginalised or restrained to merely small and powerless firms. Rather, power seems to be distributed along the vertical axis, between a dominant finance fraction in the upper half and a dominated technological fraction in the lower half. A glance at the articulation between cosmopolitan and national capital shows that — not surprisingly — those who rank in the Swiss Army or are members of the Swiss Rotary Club are different from those with an international career. Other capitals that one might deem to be rather national in character are not so clearly opposed to cosmopolitan capital. There is no significant negative link between internationality and Swiss political capital. It is possible to cultivate a privileged linked to Swiss politics or to occupy a central position in the network of Swiss firms and to pursue at the same time an international career. In other words: national and international forms of capital are not mutually exclusive but can sometimes be held simultaneously. We can observe a differentiation neither between international Swiss managers and national Swiss managers nor among different types of international careers of foreign managers.

\section{The Field of the Swiss Business Elite in 2010}

The same type of analysis has then been repeated for $2010^{14}$ —again we present a table of the eigenvalues and modified rates, before presenting the cloud of categories and the cloud of individuals.

\section{Table 6 about here}

Figure 2 about here 
The questions that most importantly contribute to explaining the variance of the first axis $(80.3 \%)$ are the following eight: Internationality of Career (20.6\%), Country (18.0\%), Employees abroad (9.7\%), Rotary Club (9.2\%), Army (8.8\%), Stock Listing (8.8\%), Number of Employees (7.5\%) and University (7.4\%). The following 17 items have been retained for the interpretation of the horizontal axis. On the left side are situated Stock High (5.0\%), ++ Employees Abroad (4.9\%), Foreigner Career Swiss (4.5\%), Foreigner Career International (3.9\%), No Army (3.0\%), Country Asia/Africa (3.0\%), Country Europe (2.6\%) and Foreigner Career National (2.2\%). On the right side are located Country Switzerland (10.5\%), Swiss Career Swiss (9.8\%), Rotary Yes (7.6\%), -- Employees Abroad (4.6\%), Employees Few (4.4\%), Yes Political Group (3.7\%), Captain/Major (3.2\%), Lieutenant (2.7\%) and Uni romandes (2.4\%). The second axis is determined by the six following questions, adding up to 58.5 of the explained variance: Firm Centrality (16.5\%), Sector (12.8\%), Employees Abroad (12.7\%), Country (10.0\%), Stock Listing (9.3\%) and University (7.2\%). Fourteen items have been retained to interpret the second axis. In the upper half of the plan we can see Centrality 1-20 (12.8\%), + Employees Abroad (7.4\%), Law (5.0\%), UniZh (4.6\%), Country Asia (4.4\%), Swiss Career International (3.5\%), Employees Many (3.4\%) and Rotary Yes $(3.3 \%)$. In the lower half of the plane are situated the following items: Service Sector (8.3\%), No Stock Listing (4.9\%), Country Europe (4.2\%), No University (3.8\%), Centrality 50+ (3.7\%) and -- Employees Abroad (2.7\%).

In 2010 the first axis was still strongly defined by cosmopolitan capital. In contrast to 2000, however, high cosmopolitan capitals seem now to be much more closely associated to economic capital: the managers in possession of high cosmopolitan capital are those who manage the best capitalised and biggest Swiss firms. As opposed to this, managers with careers confined to Switzerland (on the right) are now associated with smaller and less powerful firms. Interestingly, this is not due to a different relation of the cosmopolitan fraction to national capitals. Whereas Army ranks and Rotary Club membership are still in an opposing relationship to cosmopolitan capital, other forms of potentially national capitals, such as 
centrality in the corporate network or participation in business associations, are still not directly related to the possession of cosmopolitan capital. This means that in 2010 cosmopolitan capital itself had become more important to accede the most powerful position in the Swiss business field. At the same time, we seem to observe an internal differentiation of Swiss managers: managers with Swiss citizenship are increasingly divided between those who evolve within an exclusively national framework and those who leave Switzerland for an international career. The latter group's career and experience might compare rather closely to the career patterns of international managers of foreign origin. Among foreign managers of Swiss firms, it seems that those with an international career in Asia are closer to powerful positions than those whose path has led them through Europe or America.

\section{Foreign Newcomers and the Marginalisation of Traditional Swiss Business Elites}

The recent globalisation has led to the emergence of an international business elite field-but also to a reconfiguration of national business elite fields. In order to understand this second phenomenon we introduced the notion of cosmopolitan capital. With this concept it becomes possible to describe the increasing internationalisation of the Swiss business elite, to investigate the link between power and internationality, to shed light on the relations between international and national forms of capital and to examine the possible differentiation of the groups of Swiss and foreign top managers. Based on a multiple correspondence analysis of the years 2000 and 2010, we can give the following answers to our four research questions:

(a) Switzerland, as a small open economy (Katzenstein, 2003; Heilbron, 2001), seems to be particularly exposed to globalisation, and its business elites have been internationalised at an amazing pace. Especially the years between 2000 and 2010 seem to be a period of accelerated transnationalisation (Caroll, 2010). What is more, the careers of top managers became 
increasingly transnational and travelled through several countries instead of only corresponding to a simple move from their motherland to Switzerland. As an echo of this internationalisation, national capitals (army, extra-parliamentary commissions, political groups) are in decline.

(b) Foreign managers have not only become numerically more important among Swiss business elites, but they also have slowly conquered the apex of the biggest and highest capitalised Swiss firms. In 2010 the most powerful Swiss firms were managed by international managers with transnational careers and global networks. Brady Dougan of Credit Suisse is a particularly telling example, but no exception. Most of the formerly heraldic Swiss firms such as UBS, Credit Suisse, Nestlé, ABB, Novartis or Roche are now managed by foreign managers. The field of the Swiss business elite has been 'colonised' by a very internationalised elite fraction. In other words: cosmopolitan capital is in Switzerland one of the most powerful power resources which increasingly outstrips national forms of capitals. This symbolically strong legitimisation of cosmopolitan forms of capital in the elite field echoes results from analyses of a broader cultural field and relations between class fractions more generally (Prieur and Savage, 2011).

(c) The relation between international and national forms of capital remains however ambiguous: while certain formal forms of national capitals such as military or, to a certain degree, political memberships are exclusive with respect to cosmopolitan capital, others are not. In particular, firm networks are no longer a specifically national type of capital and thus not used in order to exclude foreign managers. Similarly, holding an MBA in a prestigious Business school is often combined with an education background in a national university.

(d) This might also be due to the fact that both sides-foreign and Swiss managers - are evolving. Whereas the most traditional fractions of the Swiss business elite are clearly marginalised, it seems that some Swiss managers become increasingly international. The pressure from the outside thus leads to a differentiation within the Swiss business elites, creates and reinforces a Swiss-international fraction and thereby begins to blur the boundary between what can be considered as Swiss and what as foreign. 
In conclusion, we would like to argue that a concept such as cosmopolitan capital should be further used in the future. Even though it might be theoretically difficult to differentiate from other forms of cultural or social capitals, the application to the Swiss case shows that it can be heuristically useful. It allows the researcher to overcome or at least attenuate some dangers of methodological nationalism from which field analysis is not immune. In the present time of crises it would be interesting to investigate whether this internationalisation has been slowed down or if we can even observe, as part of a new economic patriotism, a certain return to more national (and symbolically more 'trustworthy') managers.

\section{References:}

Bennett T, Savage M, Silva E, Warde A, Gayo-Cal M and Wright D (2009) Culture, Class, Distinction. London : Routledge.

Bourdieu P (1980) Le capital social. Actes de la recherche en sciences sociales 31(1):2-3.

Bourdieu P (1986) The forms of capital. In: Richardson JG (ed.) Handbook of Theory and Research for the Sociology of Education. New York: Greenwood, pp. 241-258.

Bourdieu P (1989) La noblesse d'état. Grandes écoles et esprit de corps. Paris: Minuit.

Bourdieu P (1993) Some properties of fields. In: Bourdieu P Sociology in question. London : Sage, pp. $72-77$.

Bourdieu P (2000) Du champ national au champ international. In : Bourdieu P Les structures sociales de l'économie. Paris : Seuil (collection Liber), pp. 271-282.

Bourdieu P (2002) Les conditions sociales de la circulation internationale des idées. Actes de la recherche en sciences sociales 145 (1): 3-8.

Bourdieu P and De St. Martin M (1978) Le patronat. Actes de la recherche en sciences sociales 20-21: $3-82$. 
Bourdieu P and Wacquant L (1992) An Invitation to Reflexive Sociology. Chicago : Chicago University Press.

Boyer R (2003) L'anthropologie économique de Pierre Bourdieu. Actes de la recherche en sciences sociales $150: 65-78$.

Bühlmann F, David T and Mach A (2012) The Swiss Business Elite (1980-2000): How the Changing Composition of the Elite Explains the Decline of the Swiss Company Network. Economy and Society 41(2): 1-28.

Bühlmann F, David T and Mach A (forthcoming) Political and Economic Elites in Switzerland: personal interchange, interactional relations and structural homology. European societies.

Calhoun C (2003) “Belonging” in the Cosmopolitan Imaginary. Ethnicities 3(4): 531-68.

Carroll WK (2010) The Making of a Transnational Capitalist Class: Corporate Power in the 21st Century. London: Zed Books.

Caroll WK and Fennema M (2002) Is there a transnational business community? International Sociology 17(3): 393-419.

David T, Mach A, Lüepold M and Schnyder G (2012) De la 'forteresse des Alpes' à la valeur actionnariale: Histoire du gouvernement d'entreprise suisse au $20^{e}$ siècle. Zurich: Seismo.

David T, Davoine E, Mach A, Ginalski S and Ravasi C (forthcoming) The emergence of a transnational economic elite at the age of globalization: the case of Swiss large corporations (1980-2010).

Davoine E and Ravasi C (forthcoming) The relative stability of national career patterns in European top management careers in the age of globalisation: A comparative study in France/Germany/Great Britain and Switzerland. European Management Journal.

Denord F, Lagneau-Ymonet P and Thine S (2011) Le champ de pouvoir en France. Actes de la recherche en sciences sociales, $190: 24-57$.

Dezalay Y (2004) Les courtiers de l'international. Héritiers cosmpolites, mercenaires de l'impérialisme et missionaires de l'universel. Actes de la recherche en sciences sociales 151-152: 5-35.

Fennama M (1982) International Networks of Banks and Industry. The Hague: Nijhoff. 
Fligstein N (2008) Euroclash: the EU, European identity, and the future of Europe. Oxford: Oxford University Press.

Gingras Y (2002) Les formes spécifiques de l'internationalité du champ scientifique. Actes de la recherche en sciences sociales 141-142: 31-45.

Hartmann M (2011) Internationalisation et spécificités nationales des élites économiques. Actes de la recherche en sciences sociales 190: 10-23.

Heilbron J (2001) Echanges culturels transnationaux et mondialisation: quelques reflexions. Regards sociologiques 22: 141-154.

Jann B (2003) Old Boy Network: Militärdienst und ziviler Berufserfolg in der Schweiz. Zeitschrift für Soziologie 32(2): 139-155.

Katzenstein PJ (2003) Small states and small states revisited. New Political Economy 8 (1): 9-30.

Kentor J and Jang Y S (2004) Yes, there is a (growing) transnational business community: A study of global interlocking directorates 1983-98. International Sociology 19(3): 355-68.

Lüchinger R and Nolmans E (2003) Rainer E. Gut: Bankier der Macht. Anatomie einer Karriere. Zürich: Bilanz Verlag.

Mach A, David T and Bühlmann F (2011) La fragilité des liens nationaux. La reconfiguration de l'élite de pouvoir en Suisse, 1980-2010. Actes de la recherche en sciences sociales 190 : 78-107.

Prieur A and Savage M (2011) Updating Cultural Capital Theory: A Discussion based on Studies in Denmark and Britain. Poetics 39(6): 566-580.

Sapiro G (2010) Globalization and cultural diversity in the book market : the case of translations in the US and in France. Poetics 38(4): 419-439.

Sklair L (2001) The transnational capitalist class. New York: Wiley-Blackwell.

Stokman F N, Ziegler R and Scott J (1985) Networks of Corporate Power. A Comparataive Analysis of Ten Countries. Cambridge: Polity Press. 
Van Veen K and Kratzer J (2011) National and international intelrocking directorates within Europe: coroporate networks within and among fifteen European countries. Economy and Society 40(1): $1-25$.

Wagner A-C (2007) Les classes sociales dans la mondialisation. Paris: Découverte. 
Tables and Figures

Table 1: Foreign top-managers in large Swiss firms 1980-2010

\begin{tabular}{llll}
\hline & $\mathbf{1 9 8 0}$ & $\mathbf{2 0 0 0}$ & $\mathbf{2 0 1 0}$ \\
Swiss Citizens & $96.3 \%$ & $77.2 \%$ & $65.5 \%$ \\
Europeans Foreigners & $3.2 \%$ & $21.7 \%$ & $28.5 \%$ \\
Non-European Foreigners & $0.5 \%$ & $1.1 \%$ & $6.0 \%$ \\
\hline
\end{tabular}

Table 2: Career place of foreign managers 1980-2010

\begin{tabular}{llll}
\hline & $\mathbf{1 9 8 0}$ & $\mathbf{2 0 0 0}$ & $\mathbf{2 0 1 0}$ \\
Career within Switzerland & $42.8 \%$ & $17.9 \%$ & $12.1 \%$ \\
Career in mother country & $0.0 \%$ & $38.4 \%$ & $25.8 \%$ \\
Career through several foreign countries & $14.2 \%$ & $30.8 \%$ & $59.1 \%$ \\
Missing & $42.8 \%$ & $12.8 \%$ & $3.0 \%$ \\
\hline Total $\mathrm{n}$ & 7 & 39 & 66 \\
\hline
\end{tabular}

Table 3: Number of Swiss and foreign top-managers holding MBA degrees 1980-2010

\begin{tabular}{llll}
\hline & $\mathbf{1 9 8 0}$ & $\mathbf{2 0 0 0}$ & $\mathbf{2 0 1 0}$ \\
MBA & $5.23 \%$ & $17.4 \%$ & $26.7 \%$ \\
\hline
\end{tabular}

Table 4: Top-managers with national capital (only Swiss citizens)

\begin{tabular}{llll}
\hline & $\mathbf{1 9 8 0}$ & $\mathbf{2 0 0 0}$ & $\mathbf{2 0 1 0}$ \\
Extra-parliamentary commission & & & \\
Party function & $19.9 \%$ & $6.0 \%$ & $1.5 \%$ \\
Military Rank & $5.2 \%$ & $0.5 \%$ & $1.5 \%$ \\
\hline
\end{tabular}


Table 5: Eigenvalue and Modified Rates (2000)

\begin{tabular}{lllll}
\hline Axis & 1 & 2 & 3 & 4 \\
Eigenvalue & 0.20 & 0.16 & 0.15 & 0.12 \\
Modified rate & 0.46 & 0.20 & 0.17 & 0.07 \\
\hline
\end{tabular}

Table 6: Eigenvalues and Modified Rates (2010)

\begin{tabular}{lllll}
\hline Axis & 1 & 2 & 3 & 4 \\
Eigenvalue & 0.23 & 0.16 & 0.14 & 0.14 \\
Modified rate & 0.55 & 0.16 & 0.09 & 0.08 \\
\hline
\end{tabular}

Figure 1: Cloud of categories of the Swiss business elites 2000

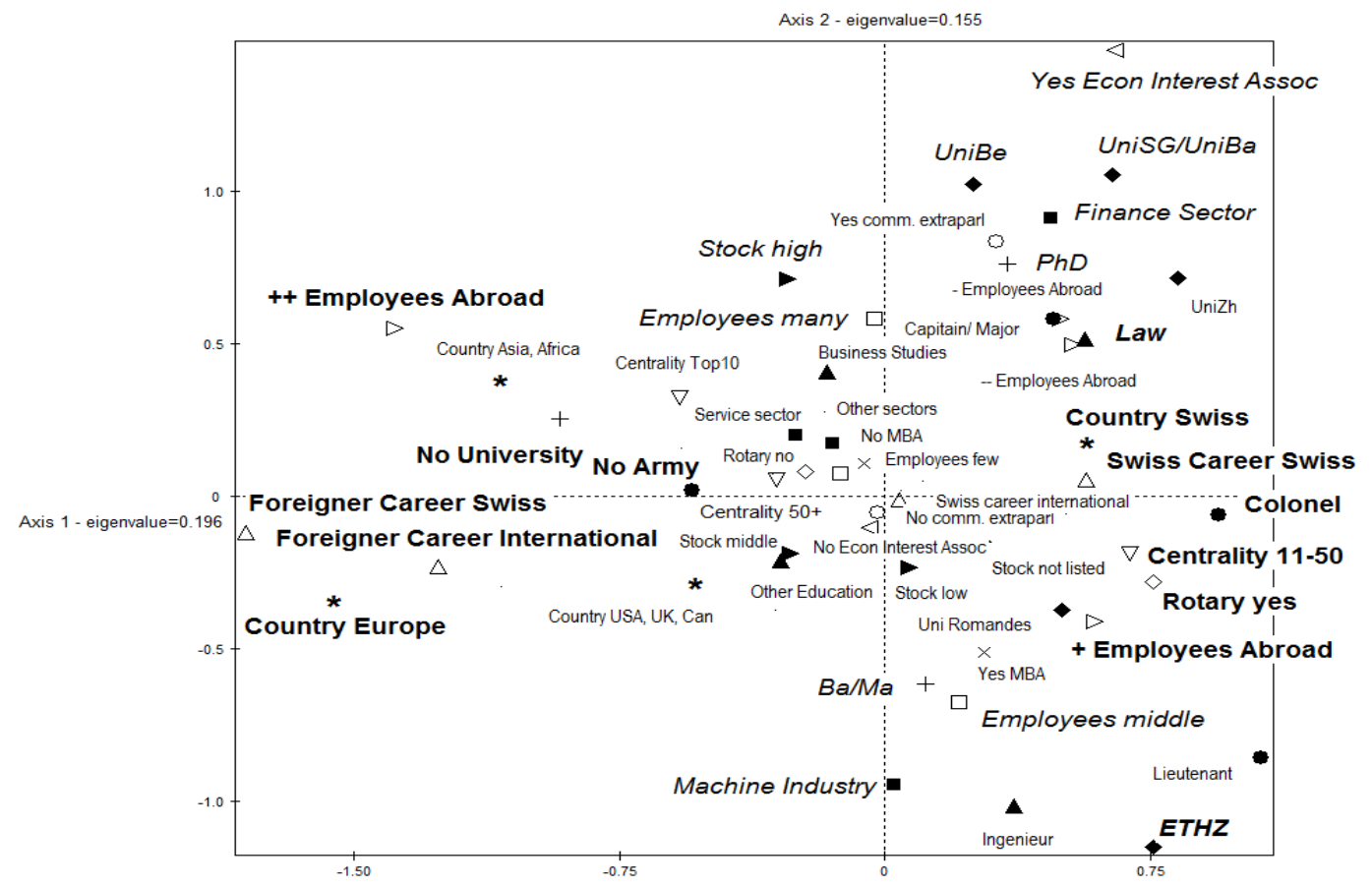

Legend : extra-parliamentary commission : $\bigcirc$; Economic Interest Group: $\triangleleft$; Rotary Club: $\diamond$; Army: $\bullet$; Network centrality: $\nabla$; Educational Level: +; Discipline of study: $\mathbf{\Delta}$; University: $\bullet$; Economic Sector: $\mathbf{\square}$; Stock listing: $>$; Number of employees: $\square$; Country: *; MBA: X; Employees abroad : $\triangleright$; Internationality of career : $\triangle$; Labels: bold : categories retained for first axis ; italics : categories retained for second axis ; bold italics : categories retained for both axes. 
Figure 2: Cloud of categories of the Swiss business elites 2010

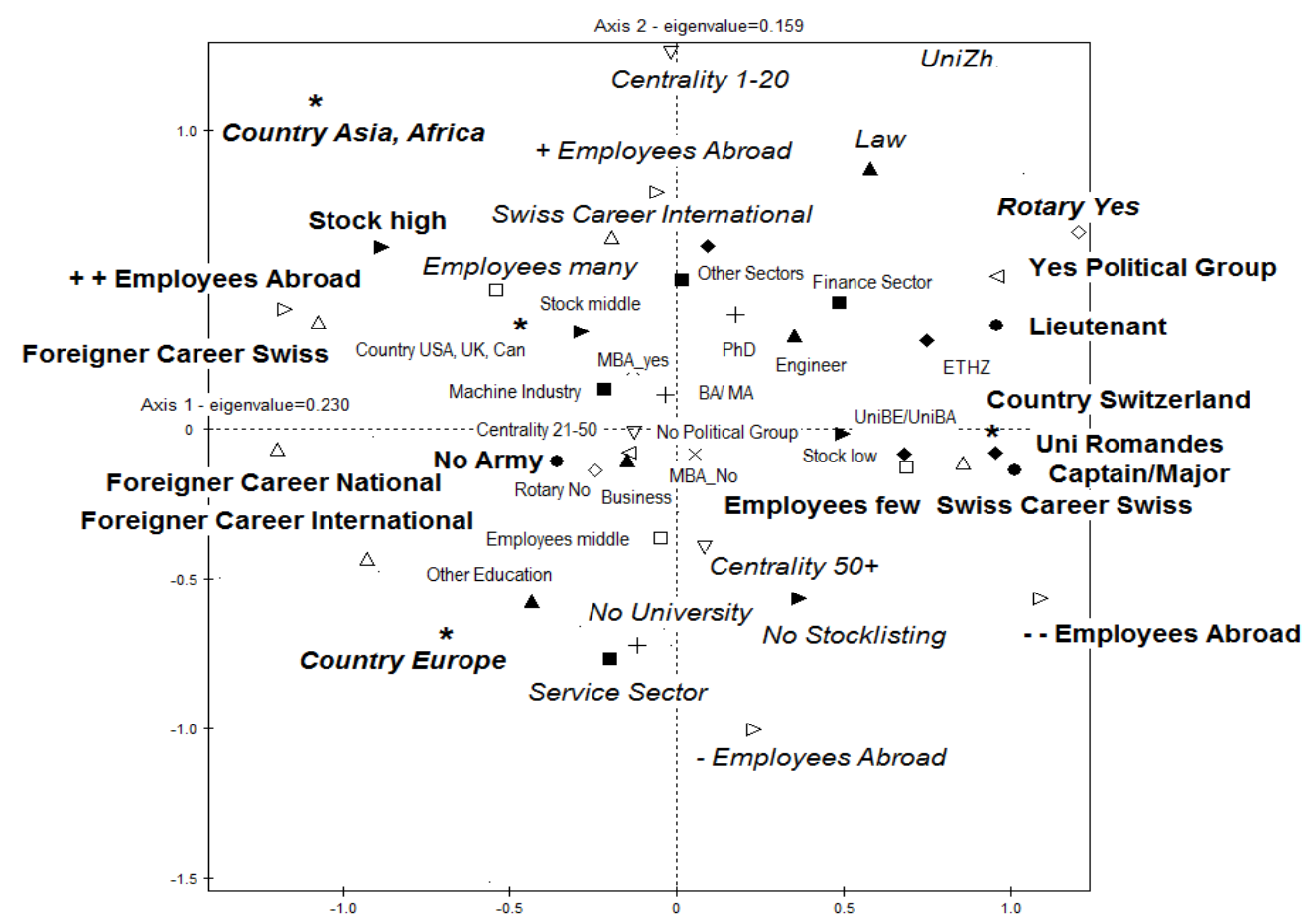

Legend : extra-parliamentary commission : $\bigcirc$; Economic Interest Group: $\triangleleft$; Rotary Club: $\diamond$; Army: $\bullet$; Network centrality: $\nabla$; Educational Level: +; Discipline of study: $\boldsymbol{\Delta}$; University: $\diamond$; Economic Sector: $\mathbf{\square}$; Stock listing: $\downarrow$; Number of employees: $\square$; Country: *; MBA: X; Employees abroad : $\triangleright$; Internationality of career : $\triangle$; Labels: bold : categories retained for first axis ; italics : categories retained for second axis ; bold italics : categories retained for both axes. 


\begin{tabular}{|c|c|c|c|c|c|c|c|c|}
\hline \multicolumn{3}{|c|}{ Contributions of Active Variables } & \multicolumn{2}{|c|}{2000} & \multirow[b]{2}{*}{$\mathbf{n}$} & \multicolumn{3}{|c|}{2010} \\
\hline Segment & Variables & Modalities & Axis 1 & Axis 2 & & Axis 1 & Axis 2 & $\mathbf{n}$ \\
\hline \multirow{9}{*}{ 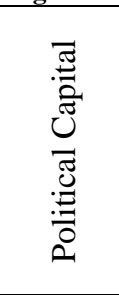 } & \multirow{3}{*}{$\begin{array}{l}\text { Economic Interest } \\
\text { Association }\end{array}$} & Eco Interest Yes & 0.9 & 6.0 & 12 & -- & -- & \\
\hline & & Eco Interest No & 0.1 & 0.4 & 172 & -- & -- & \\
\hline & & TOTAL & 1 & 6.4 & 184 & -- & -- & \\
\hline & \multirow{3}{*}{$\begin{array}{l}\text { Extra- } \\
\text { parliamentary } \\
\text { commission }\end{array}$} & Comm. ex. parl Yes & 0.2 & 1.8 & 11 & -- & -- & \\
\hline & & Comm ex. parl No & 0.0 & 0.1 & 173 & -- & -- & \\
\hline & & TOTAL & 0.2 & 1.9 & 184 & -- & -- & \\
\hline & \multirow{3}{*}{$\begin{array}{l}\text { Political } \\
\text { Association }\end{array}$} & Political Association Yes & -- & -- & -- & 0.6 & 0.2 & 174 \\
\hline & & Political Association No & -- & -- & -- & 3.7 & 1.5 & 26 \\
\hline & & TOTAL & -- & -- & -- & 4.3 & 1.7 & 200 \\
\hline \multirow{12}{*}{ 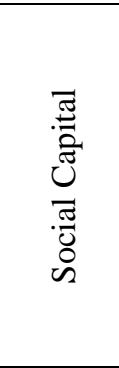 } & & No Rotary & 1.3 & 0.2 & 142 & 1.6 & 0.7 & 166 \\
\hline & Rotary & Yes Rotary & 4.4 & 0.8 & 42 & 7.6 & 3.3 & 34 \\
\hline & & TOTAL & 5.7 & 1.0 & 184 & 9.2 & 4.0 & 200 \\
\hline & & No Military Grade & 6.1 & 0.0 & 112 & 3.0 & 0.4 & 147 \\
\hline & Military Panl & Lieutenant & 2.5 & 2.1 & 12 & 2.7 & 0.5 & 19 \\
\hline & Mintary Rank & Captain/Major & 0.7 & 1.4 & 18 & 3.2 & 0.1 & 20 \\
\hline & & Colonel & 6.9 & 0.0 & 42 & -- & -- & -- \\
\hline & & TOTAL & 16.2 & 3.5 & 184 & 8.8 & 1.0 & 186 \\
\hline & & Centrality 1-10 & 1.1 & 0.4 & 17 & 0.0 & 12.8 & 36 \\
\hline & Sector & Centrality $11-50$ & 5.4 & 0.5 & 61 & 0.1 & 0.0 & 56 \\
\hline & & Centrality $50+$ & 1.8 & 0.1 & 106 & 0.1 & 3.7 & 106 \\
\hline & & TOTAL & 8.2 & 1.0 & 184 & 0.3 & 16.5 & 198 \\
\hline & & Non-Academic & 4.4 & 0.4 & 28 & 0.1 & 3.8 & 32 \\
\hline & & BA/MA & 0.2 & 7.6 & 86 & 0.0 & 0.3 & 111 \\
\hline & Educational Level & $\mathrm{PhD}$ & 1.2 & 7.3 & 54 & 0.2 & 1.5 & 46 \\
\hline & & TOTAL & 5.8 & 15.3 & 168 & 0.3 & 5.6 & 189 \\
\hline & & Law & 2.2 & 2.3 & 37 & 1.6 & 5.2 & 30 \\
\hline 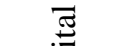 & Tyne of Education & Business & 0.2 & 1.9 & 49 & 0.3 & 0.2 & 88 \\
\hline 卷 & Type of Education & Other Education & 0.3 & 0.2 & 21 & 0.7 & 1.8 & 24 \\
\hline U & & TOTAL & 2.7 & 4.4 & 107 & 2.6 & 7.1 & 142 \\
\hline สี & & ETHZ & 3.0 & 9.0 & 29 & 2.1 & 0.5 & 24 \\
\hline$\tilde{0}$ & & Uni Zurich & 1.5 & 1.4 & 12 & 1.9 & 4.6 & 14 \\
\hline : & & Uni Bern & 0.1 & 2.4 & 10 & -- & -- & --- \\
\hline ש & University & Uni St. Gall/ Basel & 1.6 & 5.5 & 21 & -- & -- & -- \\
\hline $\overrightarrow{7}$ & & Uni St. Gall & -- & -- & & 0.0 & 2.1 & 25 \\
\hline & & Uni Bern/ Basel & -- & -- & & 0.9 & 0.0 & 13 \\
\hline & & Uni Frenchspeaking & 0.7 & 0.5 & 16 & 2.4 & 0.0 & 17 \\
\hline & & TOTAL & 7.0 & 18.8 & 88 & 7.4 & 7.2 & 93 \\
\hline & & No MBA & 0.1 & 0.4 & 152 & 0.2 & 0.5 & 142 \\
\hline & MBA & Yes MBA & 0.5 & 1.9 & 32 & 0.1 & 0.2 & 58 \\
\hline & & TOTAL & 0.6 & 2.4 & 184 & 0.2 & 0.7 & 200 \\
\hline & & Service Sector & 0.6 & 0.5 & 56 & 0.4 & 8.3 & 62 \\
\hline & & Finance Sector & 1.5 & 7.4 & 38 & 1.7 & 1.8 & 45 \\
\hline & Sector & Machine Industry & 0.0 & 11.5 & 55 & 0.3 & 0.2 & 48 \\
\hline స్ & & Other Sectors & 0.1 & 0.2 & 35 & 0.0 & 2.5 & 45 \\
\hline$\vec{z}$ & & TOTAL & 2.3 & 19.6 & 184 & 2.4 & 12.8 & 200 \\
\hline$U^{\pi}$ & & Stock not listed & 0.8 & 0.3 & 61 & 1.4 & 4.9 & 67 \\
\hline$\underline{u}$ & & Stock low & 0.0 & 0.6 & 47 & 1.9 & 0.0 & 49 \\
\hline $\bar{\Xi}$ & Market & Stock middle & 0.5 & 0.3 & 37 & 0.6 & 1.0 & 43 \\
\hline 0 & & Stock high & 0.5 & 4.5 & 38 & 5.0 & 3.4 & 41 \\
\hline ธี & & TOTAL & 1.9 & 5.7 & 183 & 8.8 & 9.3 & 200 \\
\hline & & Employees few & 0.1 & 0.1 & 46 & 4.4 & 0.2 & 59 \\
\hline & Number of & Employees middle & 0.5 & 6.4 & 60 & 0.0 & 2.0 & 66 \\
\hline & employees & Employees many & 0.0 & 4.9 & 62 & 3.1 & 3.4 & 70 \\
\hline & & TOTAL & 0.6 & 11.3 & 168 & 7.5 & 5.6 & 195 \\
\hline & & International FOREIGN & & & & 3.9 & 1.2 & 29 \\
\hline & & National FOREIGN & 4.1 & 0.2 & 14 & 2.2 & 0.0 & 10 \\
\hline & International & Swiss FOREIGN & 10.8 & 0.1 & 18 & 4.5 & 0.7 & 25 \\
\hline & Career & International SWISS & 0.0 & 0.0 & 21 & 0.2 & 3.5 & 38 \\
\hline 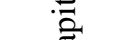 & & National SWISS & 4.9 & 0.1 & 83 & 9.8 & 0.2 & 86 \\
\hline (ָ) & & TOTAL & 19.9 & 0.3 & 136 & 20.6 & 5.7 & 188 \\
\hline$=$ & & Country Swiss & 5.1 & 0.4 & 80 & 10.5 & 0.0 & 73 \\
\hline 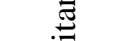 & & Country Europe & 9.2 & 0.7 & 21 & 2.6 & 4.2 & 37 \\
\hline$\overline{0}$ & Type of Country & Country USA, UK, Can & 1.4 & 0.6 & 28 & 1.9 & 1.4 & 59 \\
\hline ô & & Country Asia & -- & -- & 5 & 3.0 & 4.4 & 17 \\
\hline$\tilde{E}$ & & TOTAL & 15.6 & 1.7 & 129 & 18.0 & $\mathbf{1 0 . 0}$ & 186 \\
\hline 8 & & Very few Empl. abroad & 1.8 & 2.0 & 35 & 4.6 & 1.8 & 25 \\
\hline & Employees & Few Empl. abroad & 1.0 & 1.7 & 22 & 0.1 & 2.7 & 12 \\
\hline & Abroad & Many Empl. abroad & 2.2 & 1.4 & 35 & 0.0 & 7.4 & 52 \\
\hline & & Very many Empl. abroad & 7.1 & 1.4 & 20 & 4.9 & 0.8 & 23 \\
\hline
\end{tabular}


TOTAL

\begin{tabular}{l|r}
12.1 & 6.5 \\
\hline
\end{tabular}

\begin{tabular}{|l|c|}
\hline 112 & 9.7 \\
\hline
\end{tabular}

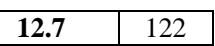

Bold: categories > average contribution (for the year 2000: 100/15=6.67; for the year 2010: 100/14=7.14); Italics: modalities > average contribution (for the year 2000: 100/48=2.08; for the year 2010: 100/47=2.12)

\footnotetext{
${ }^{1}$ This paper is a result of the research project 'Les élites suisses au 20e siècle: un processus de différenciation inachevé?' directed by Andre Mach and Thomas David and funded by the Swiss National Science Foundation ( ${ }^{\circ}$ 113550). In addition, the authors benefited from the support of the National Competence Centre in Research LIVES, which is financed by the Swiss National Science Foundation. The authors are grateful to the Swiss National Science Foundation for its financial support. We would like to thank Mike Savage, Elizabeth Silva, three anonymous reviewers and all the participants of the SCUD conference in May 2011 at York for their very helpful comments.

${ }^{2}$ Independently of their actual nationality, we will consistently call 'Swiss' business elite all the top managers of the most important Swiss firms, even though the aim of this paper is to show how they become less and less 'Swiss'.

3 'Dans l'espace des pratiques internationales, les opérateurs dominants sont ceux qui peuvent mobiliser des ressources acquises et homologuées dans des champs nationaux de pouvoir, en particulier des titres et des diplômes d'État. En contrepartie: la mobilisation d'un capital international de compétences et de relations représente un atout non négligeable dans les stratégies de pouvoir dans le champ national' (Dezalay, 2004: 7).

${ }^{4}$ For instance, in the form of an international network of interlocking directorates among multinational firms, a landscape of internationally recognised universities or international meeting places (such as the WEF in Davos or the Bilderberg conference).

${ }^{5}$ According to Boyer, the entry of new actors into the field and the redefinition of the relations between fields are two of the major mechanisms that can lead to changes of field structures (Boyer, 2003).

${ }^{6}$ According to Bourdieu, 'les économies nationales dominantes tendent, par leur seul poids dans la structure (qui fonctionne comme barrière à l'entrée), à concentrer les actifs des entreprises et à s'approprier les profits qu'elles produisent, ainsi qu'à orienter les tendances du fonctionnement du champ' (Bourdieu, 2000: 276).

7 The data for the years 1980 and 2000 were collected by Stéphanie Ginalski, Fréderic Rebmann, Steven Piguet and Andrea Pilotti from the University of Lausanne. For the year 2010, the data were collected in collaboration with Claudio Ravasi and Eric Davoine from the chair of Human Resources and Organisation at the University of Fribourg.

8 A sort of lay administration, where important organisations defend private interests in the political sphere.

9

For this categorisation the firms have been divided arithmetically into three groups according to the amount of their capitalisation. Firms with 'high capitalisation', for instance, belong to the third of the firms with the highest capitalisation.

${ }^{10}$ For lack of data we are not able to integrate aspects of transnational social capital.

${ }^{11}$ Also the foreign direct investments of Swiss companies rose exponentially during the same period (David et al., 2012).

1226 of the 43 foreign managers in 2000 came from the neighbour countries Germany, Austria, France and Italy.

${ }^{13}$ As we do not further comment upon the clouds of individuals we refrain from displaying them here. Upon request, they are available from the authors.

${ }^{14}$ For several reasons we opted for a construction of an independent space in 2010, instead of projecting the variables of 2010 as passive variables into the space of 2000: some of the variables of 2000 have been abandoned or replaced in 2010, and the operationalisation was also modified in some cases in order to better account for the realities of 2010. In addition, we have a large number of active variables which would make a single space difficult to interpret.
} 